\title{
Relationship of Zinc and Magnesium Serum Levels with Postpartum Depression in Tabriz-Iran
}

\author{
Fatemeh Edalati-Fard ${ }^{1}$, Mojgan Mirghafourvand ${ }^{2}$, Sakineh Mohammad-Alizadeh-Charandabi ${ }^{2,3}$ \& Azizeh \\ Farshbaf-Khalili ${ }^{2,4}$ \\ ${ }^{1}$ Students' Research Committee, Tabriz University of Medical Sciences, Tabriz, Iran \\ ${ }^{2}$ Faculty of Nursing and Midwifery, Tabriz University of Medical Sciences, Tabriz, Iran \\ ${ }^{3}$ Social Determinants of Health Research Center, Tabriz University of Medical Sciences, Tabriz, Iran \\ ${ }^{4}$ Health Services Management Research Center, Tabriz University of Medical Sciences, Tabriz, Iran \\ Correspondence: Mojgan Mirghafourvand, Midwifery Department, Tabriz University of Medical Sciences, Iran. \\ Tel: 98-41-3477-2699. E-mail: mirghafourvandm@tbzmed.ac.ir
}

Received: December 25, 2015 Accepted: January 27, 2016 Online Published: February 29, 2016

doi:10.5539/gjhs.v8n11p120

URL: http://dx.doi.org/10.5539/gjhs.v8n11p120

\begin{abstract}
Objective: According to the World Health Organization, depression will be the second prevalent problem after ischemic heart diseases by the year 2020. Postpartum depression (PPD) as a major depressive episode has devastating impacts on the health of mother, newborn, infant, and even the whole family. This study was conducted to investigate the relationship of zinc and magnesium serum levels with PPD, as one of the commonly assumed causes of depression.
\end{abstract}

Methods: This cross-sectional study was done on 122 postpartum women aged 18 years and more in two educational hospitals and one non-educational hospital in Tabriz-Iran, 2015. The eligible women were selected using convenience sampling method. Then, the demographic characteristics questionnaire and Edinburgh Depression Scale were completed by participants, and 5cc of blood sample was drawn from each participant. For data analysis, logistic regression test was used.

Results: The mean score of depression scale was 8.0 (SD: 4.7), meaning that $18.9 \%$ of mothers were depressed. Results indicated a significant inverse correlation between Edinburgh depression score and magnesium serum level $(\mathrm{p}=0.001)$. However, there was no statistically significant relationship between the zinc serum level and Edinburgh depression score $(\mathrm{p}=0.831)$, in so far as based on logistic regression analysis, increased magnesium serum level decreased the odds of depression [Odds ratio: 0.05; CI 95\%: 0.01 to 0.29].

Conclusions: In this study, there was a significant inverse relationship between magnesium serum level and Edinburgh depression score.

Keywords: depression, Zinc, Magnesium, postpartum, postpartum depression, serum

\section{Introduction}

According to World Health Organization (WHO), depression will become the second prevalent problem after ischemic heart diseases by 2020 (WHO, 2005); In addition, postpartum depression (PPD), as a major depressive episode, is diagnosed with the beginning of pregnancy, and can last from 2 weeks to 1 year (based on DSM-IV and International Classification of Diseases (ICD-10)) (Miller, Murray, Beckmann, Kent, \& Macfarlane, 2013). Depression is two times more common among women (Bodnar \& Wisner, 2005) and according to previous studies, PPD occurs in 10-20\% of all newly delivered women (Miller et al., 2013). The overall incidence of PPD in Iran has been reported as $25.4 \%$ (Veisani \& Sayehmiri, 2012).

It has devastating effect on the mother and newborn, and negatively affects family relationships and child development (Etebary, Nikseresht, Sadeghipour, \& Zarrindast, 2010; Miller et al., 2013). Such conditions can lead to child-killing thoughts, damage cognitive and social development of children (Spinelli, 2004), decrease mother-child interaction, develop bad and negative feelings about child behaviors, and weaken mother-newborn attachment. In addition, obvious developmental delay, social and interactional problems, poor speech development, long-term behavioral problems, child neglect, and marital divorce for stresses are of such effects 
(Miller et al., 2013).

Pregnancy is an important stressful life event that accelerates the intensity of depression (Cunningham et al., 2014). Several other factors are introduced as the causes of PPD, one of which is nutrient deficiency including: folate, vitamin B12, calcium, iron, selenium, zinc, and n-3 fatty acid (Leung \& Kaplan, 2009).

Zinc and magnesium are two main body elements (Szewczyk et al., 2008), which are required for the activity of 300 enzymes (Etebary et al., 2010; Nowak, Szewczyk, \& Pilc, 2005). In addition, zinc and magnesium both have a role in the regulation of neurotransmitters induction and release (Etebary et al., 2010; Smart, Hosie, \& Miller, 2004). Homeostasis changes of zinc and magnesium in brain cause behavioral disorders such as depression, headaches, generalized tonic-clonic problems such as focal epilepsy, dizziness, tremors, irritability, psychotic behavior, loss of appetite, restlessness, malaise, weakened learning and cognitive function, and some neurological disorders like epilepsy and Alzheimer (Etebary et al., 2010).

Studies show that zinc and magnesium are probably effective in the pathogenesis and therapy of depression (Cope \& Levenson, 2010; Kroczka, Branski, Palucha, Pilc, \& Nowak, 2001; Mlyniec et al., 2014). Moreover, some studies have suggested that zinc and magnesium serum level in depressive patients, especially those with PPD, is lower than non-depressed individuals (DiGirolamo \& Ramirez-Zea, 2009; Stanislawska et al., 2014; Swardfager et al., 2013). However, some other studies have not suggested any statistically significant relationship between the zinc and magnesium serum levels with depression (Crayton \& Walsh, 2007; Islam et al., 2013). The anti-depression feature of zinc and magnesium has been seen in animal studies, including on mice (Kroczka et al., 2001; Mlyniec et al., 2013; Samardzic et al., 2013; Poleszak et al., 2004). This study aims at determining the relationship between zinc and magnesium serum levels with PPD before the development of its severe symptoms and signs, as an assumed cause of PPD, to find a prevention method by keeping serum level high, in case of such relationship.

\section{Materials and Methods}

\subsection{Methodology and Participants}

This was a cross-sectional study conducted on 122 newly delivered women (within past 48 hours), hospitalized in postpartum wards of Alzahra and Taleghani (educational hospitals), and 29-Bahman Hospital (non-educational hospital) in Tabriz, Iran in 2015. This study has been approved by the Ethics Committee of Tabriz University of Medical sciences (\#93106).

Inclusion criteria were: Women aged 18 years and more, living in Tabriz, basic literacy level (reading and writing), primipara and multipara, vaginal or Cesarean section and recent low-risk pregnancy. Exclusion criteria included: hospitalization of mother for postpartum complications, no tendency to participate.

\subsection{Sampling}

Illegibility of the participants in terms of inclusion and exclusion criteria was investigated and their written consent was obtained. Then, socio-demographic questionnaire was completed by the participants. In the pilot study, sample size of the study was determined 122 cases using the relation between serum level zinc and postpartum depression $(\mathrm{OR}=0.45)$, and considering $95 \%$ confidence, $90 \%$ power, two-tailed test and utilizing G-Power 3.1.2.

\subsection{Measures}

To determine the zinc and magnesium serum levels of the participants, $5 \mathrm{cc}$ blood sample was drawn from each participant, and were centrifuged at $3500 \mathrm{rpm}$ for 10 minutes, then immediately stored at $-20^{\circ} \mathrm{C}$. Then, they were delivered to laboratory of Student Research Center of Tabriz University of Medical sciences. To examine the zinc and magnesium serum levels, spectrophotometry (using Alcyon spectrophotometer made in the USA), a Randox kit (manufactured in England) for zinc, and a kit for magnesium (made by the Pars Azmoon Company in Iran) were used. The Randox test sensitivity was up to $2 \mu \mathrm{mol} / 1$ for zinc and Pars Azmoon test sensitivity was up to $0.5 \mu \mathrm{mol} / 1$ for magnesium. The natural level was considered as $10-18 \mu \mathrm{mol} / 1$ for zinc and $1.9-3 \mathrm{mg} / \mathrm{dl}$ for magnesium, respectively. Subjects with Edinburgh score equal or higher than 12 were considered with depression problem and referred to a mental service provider.

\subsection{Data Analysis}

Data were analyzed with SPSS- version 20 using with descriptive-analytical statistics. Data normality was examined with Skeweness and Kurtosis, indicating a normal distribution. In addition, descriptive statistics, including mean (standard deviation), frequency, and percentage, were used to describe socio-demographic information and depression status. Moreover, logistic regression analysis was utilized for investigating the 
relationship of zinc and magnesium serum levels with depression. Odds ratio and $95 \%$ confidence interval was presented as effect size of relations. In all analyses, $p$-value lower than 0.05 was considered as statistically significant.

\section{Results}

The mean age of participated women was $28.1(\mathrm{SD}=5.2)$ years, and the majority of them $(91.8 \%)$ were housewives. All participants had above secondary school educational level. More than two-third (68.9\%) of the women had relatively adequate income. Among the participants, $39.3 \%$ and $60.3 \%$ were primipara and multipara (two or three), respectively. The majority of the participants (71.1\%) had intended pregnancy.

Deliveries were $37.2 \%$ via vaginal and $62.8 \%$ via cesarean section. All participants had delivered at 38 weeks or over and $63.1 \%$ of them reported high partner support. The majority of women $(98.4 \%)$ were satisfied with the baby's sex (Table 1).

Table 1. Socio-demographic characteristics of participants

\begin{tabular}{|c|c|c|c|}
\hline Characteristics & $\mathrm{n}(\%)$ & Characteristics & $\mathrm{n}(\%)$ \\
\hline Age (years) & & Husband support & \\
\hline $18-27$ & $53(43.4)$ & Low & $11(9.0)$ \\
\hline $28-37$ & $64(52.5)$ & Moderate & 34 (27.9) \\
\hline $38-47$ & $5(4.1)$ & Much & $77(63.1)$ \\
\hline $\operatorname{Mean}(\mathrm{SD})$ & $28.1(5.2)$ & Family support & \\
\hline Education & & Low & $21(17.3)$ \\
\hline Secondary & $30(24.6)$ & Moderate & $57(46.7)$ \\
\hline High school & $68(55.7)$ & Much & $44(36.0)$ \\
\hline University & $24(19.7)$ & Satisfaction from neonatal sex & $120(98.4)$ \\
\hline Job & & Husband Education ${ }^{¥}$ & \\
\hline Housewife & $112(91.8)$ & Primary school & $18(14.7)$ \\
\hline Employed & $10 \quad(8.2)$ & Secondary school & $27(22.1)$ \\
\hline BMI $\left(\mathrm{Kg} / \mathrm{m}^{2}\right)^{*}$ & $25.3(4.2)$ & High school & $14(11.5)$ \\
\hline Economic status & & Diploma & $43(35.2)$ \\
\hline Favorable & $23(18.9)$ & University & $20(16.4)$ \\
\hline Partly favorable & $84(68.9)$ & Husband Job & \\
\hline Unfavorable & $15(12.3)$ & Unemployed & $3(2.5)$ \\
\hline Gravid $^{*}$ & $1.9(0.9)$ & Employed & $19(15.6)$ \\
\hline Parity & & Worker & $47(38.5)$ \\
\hline Primiparous & $48(39.9)$ & Shopkeeper & $21(17.2)$ \\
\hline Multiparous & $74(60.6)$ & Other ${ }^{\S}$ & $32(26.2)$ \\
\hline Delivery & & Wanted pregnancy & $81(71.1)$ \\
\hline NVD & $46(37.7)$ & & \\
\hline Cesarean section & $76(62.3)$ & & \\
\hline
\end{tabular}

*Data were presented as mean (standard deviation);

${ }^{\S}$ Driver and etc;

${ }^{\ddagger}$ One person $(0.8 \%)$ was illiterate.

The mean (standard deviation) depression score was $8.0(\mathrm{SD}=4.7)$. Among 122 delivered women, 23 (18.9\%) participants obtained Edinburgh score of 12 and higher (Table 2). 
Table 2. Serum zinc and magnesium concentrations during 48 hours after delivery

\begin{tabular}{llll}
\hline & Minimum & Maximum & Mean (SD) \\
\hline $\mathrm{Zn}(\mathrm{mol} / \mathrm{l})$ & 8.25 & 15.50 & $10.09(0.95)$ \\
$\mathrm{Mg}(\mathrm{mg} / \mathrm{dl})$ & 1.72 & 3.70 & $2.42(0.38)$ \\
\hline
\end{tabular}

The mean of zinc and magnesium serum level was $10.09(\mathrm{SD}=0.95) \mu \mathrm{mol} / \mathrm{l}$ and $2.42(\mathrm{SD}=0.38) \mathrm{mg} / \mathrm{dl}$, respectively.

Results from logistic regression showed no statistical significant relationship between the zinc serum level and Edinburgh depression score $(\mathrm{p}=0.831)$. However, there was a significant inverse correlation between magnesium serum level and Edinburgh depression score $(\mathrm{p}=0.001)$; in that according to this analysis, increased magnesium serum level decreased the risk of depression [Odds ratio: 0.05; Confidence Interval 95\%: 0.01 to 0.29] (Table 3).

Table 3. The relationship between $\mathrm{Zn}$ and $\mathrm{Mg}$ serum levels and Edinburg Postnatal Depression Rating Scale (EPDRS) score

\begin{tabular}{llllll}
\hline & $\mathrm{n}$ & $\mathrm{Zn}$ & $\mathrm{Mg}$ & $\mathrm{P}$ \\
\hline Depression score & & $\mathrm{OR}(\mathrm{CI} 95 \%)^{\ddagger}$ & $\mathrm{P}$ & $\mathrm{OR}$ (CI 95\%) & 0.001 \\
\hline$<12$ (ref) & & & 0.831 & 1 & \\
\hline$\geq 12$ & 99 & 1 & & $0.05(0.01$ to 0.29$)$ & \\
\hline
\end{tabular}

* EPDR score less than 12 was reference.

$¥$ Odds ratio (95\% Confidence Interval).

\section{Discussion}

Results suggested no statistically significant correlation between zinc serum level and PPD. In contrast, there was a significant inverse relationship between magnesium serum level and PPD, in that increase of it decreased PPD risk.

According to the latest studies, the main elements such as zinc and magnesium exert their anti-depression and anti-anxiety effects via neurotransmitters. Concentration of these elements can be related to such neurotransmitters as monoamine and serotonin (Ruljancic, Mihanovic, Cepelak, Bakliza, \& Curkovic, 2013; Szewczyk et al., 2008; Szewczyk et al., 2009). Indeed, depression and anxiety relate to the dysfunction of brain glutamate system. N-methyl-d-aspartate (NMDA) (glutamate) has an important anti-depression and anti-anxiety effect. Zinc and magnesium, the potent antagonists of the NMDA receptor complex, are involved in the pathophysiology of depression and anxiety, and exhibit antidepressant and anti-anxiety activities; therefore, reduction of zinc and magnesium levels may lead to functional NMDA receptor hyperactivity (Doboszewska et al., 2015; Sowa-Kucma et al., 2013). In addition, magnesium controls HPA (Hypothalamic-pituitary-adrenal) activity, thereby decreases anxiety symptoms by the reduction of corticotrophin releasing hormone (CRH) level (Sartori, Whittle, Hetzenauer, \& Singewald, 2012).

In some studies, including a meta-analysis, zinc serum level in depressive patients was lower than non-depressive individuals (DiGirolamo \& Ramirez-Zea, 2009; Mlyniec et al., 2013; Siwek et al., 2013; Swardfager et al., 2013). Thus, low serum zinc concentrations may have a role in the pathogenesis of depression. In a review study by DiGirolamo and Ramirez-Zea, a correlation was observed between zinc serum level with mental health issues of mothers and children, including depression and ADHD (Attention Deficit Hyperactivity Disorder) (DiGirolamo \& Ramirez-Zea, 2009). The antidepressant effect of zinc was observed in animal studies, including the one by Mlyniec et al. According to this research, the administration of antidepressants for depressed mice with zinc-deficiency-diet and low serum zinc and high cortisol levels, normalized their serum zinc level; therefore, zinc deficiency is regarded as a factor involving with the pathogenesis of depression (Mlyniec et al., 2013). In a review study, Siwek et al. presented the results of some investigations about the effect of low serum zinc level on depressed patients, and proposed the measurement of blood zinc level as a depression marker; in addition, low serum zinc level was observed in depressed patients with drug resistance (Siwek et al., 2013). The study by Markiewicz-Zukowska et al. on the relationship between the concentration of serum zinc 
level and physical and mental status of nursing home residents showed a correlation between serum zinc level and mental performance. This level was higher in older non-depressed individuals with normal cognitive performance than patients with memory disorders and depressive symptoms (Markiewicz-Zukowska, Gutowska, \& Borawska, 2015).

In a study by Maserejian et al. on general population in Boston, it was found that low zinc intake from food or supplements increased the risk of depression symptoms in women and not men. This cross-sectional study recommended more relevant research, due to little number of similar investigations (Maserejian, Hall, \& McKinlay, 2012). Results of above studies are inconsistent with ours.

A study by Crayton and Walsh on pregnant women with PPD history showed that serum zinc levels were not statistically different in women with PPD history, depressed women without PPD history, and non-depressed women. These findings are consistent with ours in that no relationship was observed between depression and serum zinc level. In addition, there was no statistically significant difference in serum zinc level between depressed and non-depressed men; moreover, copper level was higher in depressed women than depressed men (Crayton \& Walsh, 2007).

According to some studies, magnesium deficiency, similar to zinc, induces depression-like behavior in mice; on the other hand, this ion exhibits antidepressant and anti-anxiety like activities in animal tests (Decollogne, Tomas, Lecerf, Adamowicz, \& Seman, 1997; Lloyd, Perkins, \& Spence, 1989; Nikseresht et al., 2012; Poleszak et al., 2004; Singewald, Sinner, Hetzenauer, Sartori, \& Murck, 2004). Moreover, some trials have shown the effect of magnesium on the treatment of psychological disorders (De Souza, Walker, Robinson, \& Bolland, 2000; Heiden et al., 1999). A systematic review also suggests that magnesium may be effective in depression therapy, but further studies are required (Derom, Sayon-Orea, Martinez-Ortega, \& Martinez-Gonzalez, 2013).

Imado et al. examined serum magnesium level in 71 hospitalized patients and outpatients with mental disorder and 30 normal people. Results showed no significant difference between patients with major depression, who were on psychiatric medication, relative to the patients who did not take the medicine. In contrast to our study, it was also shown that serum magnesium level was significantly higher in patients with mental disorders than control group (Imada et al., 2002). In addition, no statistically significant difference was observed in serum magnesium level between control and case groups in the study by Islam et al. on 50 patients with general anxiety disorder and 51 healthy individuals (Islam et al., 2013).

One reason for the inconsistency between the present study and some above investigations is because the majority of them have been done on patients with mental disorders; in addition, there is no similar research like ours that qualitatively has investigated the general population without clinical depression.

The cross-sectional nature of this study is a research limitation as its proposed relationship is not an exact causal-comparative correlation. To eliminate this limitation, performing stronger research designs such as case-control study is recommended for investigating the relationship of serum zinc and magnesium levels with PPD.

\section{Conclusion}

Results show no relationship between the serum zinc level and depression; however, a significant statistical correlation was observed between serum magnesium level and depression. Due to the importance of PPD, it is recommended that future studies be conducted on a larger number of samples. In addition to the serum levels, the intake rate of zinc and magnesium from foods or supplements which may differ in various populations should also be taken into account.

\section{Acknowledgments}

This article was in partial fulfillment of a master's thesis in midwifery that hereby is appreciated all the participants in the study.

\section{Conflict of Interest}

The authors declare that there is no conflict of interests regarding the publication of this paper.

\section{References}

Bodnar, L. M., \& Wisner, K. L. (2005). Nutrition and depression: implications for improving mental health $\begin{array}{lllll}\text { among childbearing-aged women. Biol Psychiatry, } & \text { 58(9), }\end{array}$ http://dx.doi.org/10.1016/j.biopsych.2005.05.009

Cope, E. C., \& Levenson, C. W. (2010). Role of zinc in the development and treatment of mood disorders. Curr 
Opin Clin Nutr Metab Care, 13(6), 685-689. http://dx.doi.org/10.1097/MCO.0b013e32833df61a

Crayton, J. W., \& Walsh, W. J. (2007). Elevated serum copper levels in women with a history of post-partum depression. J Trace Elem Med Biol, 21(1), 17-21. http://dx.doi.org/10.1016/j.jtemb.2006.10.001

Cunningham, F., Leveno, K. J., Bloom, S. L., Hauth, J. C., Rouse, D. J., \& Spong, C. Y. (2014). Williams Obstetrics (Vol. 2): tyuhj.

De Souza, M. C., Walker, A. F., Robinson, P. A., \& Bolland, K. (2000). A synergistic effect of a daily supplement for 1 month of $200 \mathrm{mg}$ magnesium plus $50 \mathrm{mg}$ vitamin B6 for the relief of anxiety-related premenstrual symptoms: a randomized, double-blind, crossover study. J Womens Health Gend Based Med, 9(2), 131-139. http://dx.doi.org/10.1089/152460900318623

Decollogne, S., Tomas, A., Lecerf, C., Adamowicz, E., \& Seman, M. (1997). NMDA receptor complex blockade by oral administration of magnesium: comparison with MK-801. Pharmacol Biochem Behav, 58(1), 261-268.

Derom, M. L., Sayon-Orea, C., Martinez-Ortega, J. M., \& Martinez-Gonzalez, M. A. (2013). Magnesium and $\begin{array}{lllll}\text { depression: a systematic review. Nutr Neurosci, } & \text { 16(5), }\end{array}$ http://dx.doi.org/10.1179/1476830512y.0000000044

DiGirolamo, A. M., \& Ramirez-Zea, M. (2009). Role of zinc in maternal and child mental health. Am J Clin Nutr, 89(3), 940S-945S. http://dx.doi.org/10.3945/ajen.2008.26692C

Doboszewska, U., Sowa-Kucma, M., Mlyniec, K., Pochwat, B., Holuj, M., Ostachowicz, B., . . Szewczyk, B. (2015). Zinc deficiency in rats is associated with up-regulation of hippocampal NMDA receptor. Prog Neuropsychopharmacol Biol Psychiatry, 56, 254-263. http://dx.doi.org/10.1016/j.pnpbp.2014.09.013

Etebary, S., Nikseresht, S., Sadeghipour, H. R., \& Zarrindast, M. R. (2010). Postpartum depression and role of serum trace elements. Iran J Psychiatry, 5(2), 40-46.

Heiden, A., Frey, R., Presslich, O., Blasbichler, T., Smetana, R., \& Kasper, S. (1999). Treatment of severe mania with intravenous magnesium sulphate as a supplementary therapy. Psychiatry Res, 89(3), 239-246.

Imada, Y., Yoshioka, S., Ueda, T., Katayama, S., Kuno, Y., \& Kawahara, R. (2002). Relationships between serum magnesium levels and clinical background factors in patients with mood disorders. Psychiatry Clin Neurosci, 56(5), 509-514. http://dx.doi.org/10.1046/j.1440-1819.2002.01046.x

Islam, M. R., Ahmed, M. U., Mitu, S. A., Islam, M. S., Rahman, G. K., Qusar, M. M., \& Hasnat, A. (2013). Comparative analysis of serum zinc, copper, manganese, iron, calcium, and magnesium level and complexity of interelement relations in generalized anxiety disorder patients. Biol Trace Elem Res, 154(1), 21-27. http://dx.doi.org/10.1007/s12011-013-9723-7

Kroczka, B., Branski, P., Palucha, A., Pilc, A., \& Nowak, G. (2001). Antidepressant-like properties of zinc in rodent forced swim test. Brain Research Bulletin, 55(2), 297-300.

Leung, B. M., \& Kaplan, B. J. (2009). Perinatal depression: prevalence, risks, and the nutrition link--a review of the literature. J Am Diet Assoc, 109(9), 1566-1575. http://dx.doi.org/10.1016/j.jada.2009.06.368

Lloyd, H. G., Perkins, A., \& Spence, I. (1989). Effect of magnesium on depression of the monosynaptic reflex induced by 2-chloroadenosine or hypoxia in the isolated spinal cord of neonatal rats. Neurosci Lett, 101(2), 175-181.

Markiewicz-Zukowska, R., Gutowska, A., \& Borawska, M. H. (2015). Serum zinc concentrations correlate with mental and physical status of nursing home residents. PLoS One, 10(1), e0117257. http://dx.doi.org/10.1371/journal.pone.0117257

Maserejian, N. N., Hall, S. A., \& McKinlay, J. B. (2012). Low dietary or supplemental zinc is associated with depression symptoms among women, but not men, in a population-based epidemiological survey. $J$ Affect Disord, 136(3), 781-788. http://dx.doi.org/10.1016/j.jad.2011.09.039

Miller, B. J., Murray, L., Beckmann, M. M., Kent, T., \& Macfarlane, B. (2013). Dietary supplements for preventing postnatal depression. Cochrane Database of Systematic Reviews, (10). http://dx.doi.org/10.1002/14651858.CD009104.pub2

Mlyniec, K., Budziszewska, B., Reczynski, W., Doboszewska, U., Pilc, A., \& Nowak, G. (2013). Zinc deficiency alters responsiveness to antidepressant drugs in mice. Pharmacol Rep, 65(3), 579-592.

Mlyniec, K., Doboszewska, U., Szewczyk, B., Sowa-Kucma, M., Misztak, P., Piekoszewski, W., . . Nowak, G. 
(2014). The involvement of the GPR39- $\mathrm{Zn}(2+)$-sensing receptor in the pathophysiology of depression. Studies in rodent models and suicide victims. Neuropharmacology, 79, 290-297. http://dx.doi.org/10.1016/j.neuropharm.2013.12.001

Nikseresht, S., Etebary, S., Karimian, M., Nabavizadeh, F., Zarrindast, M. R., \& Sadeghipour, H. R. (2012). Acute administration of $\mathrm{Zn}, \mathrm{Mg}$, and thiamine improves postpartum depression conditions in mice. Arch Iran Med, 15(5), 306-311. http://dx.doi.org/012155/aim.0012

Nowak, G., Szewczyk, B., \& Pilc, A. (2005). Zinc and depression. An update. Pharmacol Rep, 57(6), 713-718.

Poleszak, E., Szewczyk, B., Kedzierska, E., Wlaz, P., Pilc, A., \& Nowak, G. (2004). Antidepressant- and anxiolytic-like activity of magnesium in mice. Pharmacol Biochem Behav, 78(1), 7-12. http://dx.doi.org/10.1016/j.pbb.2004.01.006

Ruljancic, N., Mihanovic, M., Cepelak, I., Bakliza, A., \& Curkovic, K. D. (2013). Platelet serotonin and magnesium concentrations in suicidal and non-suicidal depressed patients. Magnes Res, 26(1), 9-17. http://dx.doi.org/10.1684/mrh.2013.0332

Sartori, S. B., Whittle, N., Hetzenauer, A., \& Singewald, N. (2012). Magnesium deficiency induces anxiety and HPA axis dysregulation: modulation by therapeutic drug treatment. Neuropharmacology, 62(1), 304-312. http://dx.doi.org/10.1016/j.neuropharm.2011.07.027

Singewald, N., Sinner, C., Hetzenauer, A., Sartori, S. B., \& Murck, H. (2004). Magnesium-deficient diet alters depression- and anxiety-related behavior in mice--influence of desipramine and Hypericum perforatum extract. Neuropharmacology, 47(8), 1189-1197. http://dx.doi.org/10.1016/j.neuropharm.2004.08.010

Siwek, M., Szewczyk, B., Dudek, D., Styczen, K., Sowa-Kucma, M., Mlyniec, K., . . Nowak, G. (2013). Zinc as a marker of affective disorders. Pharmacol Rep, 65(6), 1512-1518.

Smart, T., Hosie, A., \& Miller, P. (2004). $\mathrm{Zn}^{2+}$ Ions: Modulators of Excitatory and Inhibitory Synaptic Activity. Neuroscientist, 10, 432-442. http://dx.doi.org/10.1177/1073858404263463

Sowa-Kucma, M., Szewczyk, B., Sadlik, K., Piekoszewski, W., Trela, F., Opoka, W., . . Nowak, G. (2013). Zinc, magnesium and NMDA receptor alterations in the hippocampus of suicide victims. $J$ Affect Disord, 151(3), 924-931. http://dx.doi.org/10.1016/j.jad.2013.08.009

Spinelli, M. (2004). Maternal Infanticide Associated With Mental Illness: Prevention and the Promise of Saved Lives. Am J Psychiatry, 161, 1548-1557. http://dx.doi.org/10.1176/appi.ajp.161.9.1548

Stanislawska, M., Szkup-Jablonska, M., Jurczak, A., Wieder-Huszla, S., Samochowiec, A., Jasiewicz, A., . . . Grochans, E. (2014). The severity of depressive symptoms vs. serum Mg and Zn levels in postmenopausal women. Biol Trace Elem Res, 157(1), 30-35. http://dx.doi.org/10.1007/s12011-013-9866-6

Swardfager, W., Herrmann, N., Mazereeuw, G., Goldberger, K., Harimoto, T., \& Lanctot, K. L. (2013). Zinc in $\begin{array}{llll}\text { depression: A meta-analysis. Biol Psychiatry, } & \text { 74(12), }\end{array}$ http://dx.doi.org/10.1016/j.biopsych.2013.05.008

Szewczyk, B., Poleszak, E., Sowa-Kućna, M., Siwek, M., Dudek, D., Ryszewska-Pokraśniewicz, B., ... Nowak, G. (2008). Antidepressant activity of zinc and magnesium in view of the current hypotheses of antidepressant action. Pharmacological Reports, 60(5), 588-599.

Szewczyk, B., Poleszak, E., Wlaz, P., Wrobel, A., Blicharska, E., Cichy, A., . . Nowak, G. (2009). The involvement of serotonergic system in the antidepressant effect of zinc in the forced swim test. Prog Neuropsychopharmacol Biol Psychiatry, 33(2), 323-329. http://dx.doi.org/10.1016/j.pnpbp.2008.12.011

Veisani, Y., \& Sayehmiri, K. (2012). Prevalence of Postpartum Depression in Iran - A Systematic Review and Meta-Analysis. Iranina Journal of Obstetrics Gynecology and Infertility, 14.

WHO. (2005). Promoting Mental Health. In H. Herrman., S. Saxena, \& R. Moodie. (Eds.), (p. 26).

\section{Copyrights}

Copyright for this article is retained by the author(s), with first publication rights granted to the journal.

This is an open-access article distributed under the terms and conditions of the Creative Commons Attribution license (http://creativecommons.org/licenses/by/3.0/). 